\title{
A Study on the Development of Translation Competence: A Perspective of Discourse Construction
}

\author{
He Guang-hui \\ School of foreign languages \\ Wuhan Institute of Technology \\ Wuhan, China \\ hgh_1919@163.com
}

\author{
Liu Bing, Tang Min \\ School of foreign languages \\ Wuhan Institute of Technology \\ Wuhan, China
}

\begin{abstract}
The main purpose of this study is to testify the impact of discourse construction on developing students' translation competence. This paper presented the elements of translation competence based on PATCE model. We used the translation performance of 30 non-English major freshmen for data bank. Through the Corrects a Cool Web, we found that there are four problems in students' translation tasks: lack of cohesion and coherence, default of sentence structure, misuse of words and collocation mistakes. Then we used item analysis and factor analysis to test the relationship between discourse construction and translation competence. These results demonstrate that translation errors occur at every level of language, stemming from different elements of translation competence. And discourse construction penetrates the whole translation process. The outcomes of the study may aid translation teachers in designing course syllabuses by highlighting which elements of translation competence to focus on.
\end{abstract}

Keywords-translation competence; discourse construction; discourse awareness; PACTE mode

\section{INTRODUCTION}

Since prevalent use of English is related to globalization, the dominance of English is likely to continue into the future. There are a growing number of research projects focusing on the use of English as a lingua franca. However little research has been in the context of pedagogical translation on students' translation performance. This paper aims to show that translation errors may be ascribed to various causes which may be linked not only to linguistic competence, but to several other sub-competences which constitute translation competence. It is hoped that the study will raise the awareness of importance of analyzing students' translation performance and help teachers compile teaching materials.

\section{DISCOURSE CONSTRUCTION AND TRANSLATION COMPETENCE}

Halliday and Hasan [2] argue that discourse is a semantic unit rather than a formal unit, which is not made but realized by sentences. And Beaugrande and Dressler [1] define a discourse as a "communication case", which needs to meet the seven conditions: cohesion, coherence, intentionality, acceptability, informativeness, situationality and intertextuality. Apart from this, Hatim [3] points out that discourse is a unit of consistency and coherence, which is composed of one or more interrelated sentences, and has some special meaning of rhetoric.

Actually, there are a number of studies on discourse analysis and translation. In Svetlana K. Gural and Stepan A. Boyko's [8] Analysis of the Literary Text's Conceptosphere in the Process of Teaching Literary Translation, we understand that "the usage of the cognitive-discourse analysis of texts in the course of teaching of foreign language is directed to the formation of the students' abilities, creating a basis for a number of important competences. These competences will provide a deep analysis of the text structure, the interpretation of its conceptual field, selection of a more equivalent lexicon in the process of translation, which will lead to high-quality improvement on a target text translation."

Moreover, from Wu Wei's [9] Brief Analysis on Language and Language Translation from Language Analysis Angle, we know that there are three main elements in discourse: the central idea, coherence and consistency. In accordance with these three elements, discourse translation should present the essence to express the intention of the original author. Discourse construction according to the context, coherence and cohesion is indispensible in translation activity. In Zhang Meifang's [10] Information Transformation in English-Chinese Translation, we have realized the translator, both the recipient of the original text and the producer of the translation, gets the gist of whole text from the perspective of dynamic discourse. The translator needs to compare different translations especially the analysis on terms of cohesion and coherence, thus performing his translation tasks successfully.

According to Nord [6], translation tasks will motivate students with a meaningful and realistic purpose. She points out that the development of translation competence is a gradual process and that students will learn from their difficulties, problems and errors. Meanwhile she identifies the pragmatic, convention-related, linguistic, text-specific translation errors which can be linked to the elements of translation competence. Melis and Albir [5] argue that the seriousness of translation errors can only be determined in relation to the following: the

Sponsored by research project "Academic ability and cultivation mechanism of translation personnel” from Wuhan Institute of Technology 
text as a whole, coherence and cohesion of the target text, the degree of deviation from source text, the functionality of target text, the purpose of the translation. Nord also underlines the importance of translation instruction in a pedagogical context. And the analysis of source text provides valuable information for students to make decisions. This study will adopt the holistic competence model of the PACTE research group at the University of Barcelona as it is one of the most sophisticated competence models in translation studies. The latest PACTE model involves bilingual sub-competence, extra-linguistic subcompetence, knowledge about translation, instrumental subcompetence, strategic sub-competence, psycho-physiological sub-competence. This sub-competence needs to be developed in the translation classroom.

\section{RESEARCH AIM}

The aim of this corpus-based exploratory study is to investigate non-English major's translation performance through the correcting website called "Corrects A Cool Web", an online service system based on cloud computing to help teachers and students correct English translation, which can immediately generate the scores of the students by computing between the students' translation and standard corpus. The scope of this study focuses only on linguistic errors, which are logically linked to bilingual sub-competence in the PACTE model. However, these errors in the students' actual performance are not only related to language knowledge but are linked to other sub-competences. Based on these scores, this study will address the following research questions:

(1) What are the students' most typical translation errors when translating the text?

(2) What elements of translation competence may these errors be linked to?

(3) Can we develop the students' translation competence by means of discourse construction?

\section{METHOD}

\section{A. Participants and Background}

This localized empirical study was conducted at Wuhan Institute of Technology, Hubei, and China. The participants involved in this study were from 60 non-English major freshmen from two classes who attend the same translation class together. They have studied English for about eight to ten years to develop critical reading skills, improve grammatical awareness, facilitate vocabulary acquisition, and develop intercultural and communicative competence, as is essential in translation. These previous knowledge help them to make decision in translation.

\section{B. Data Collection}

Given the qualitative and exploratory nature of the research, translation-oriented text analysis is used to analyze the data. The students' task was to finish the Chinese-English translation of a short passage about the network-based economy in their translation class. The selection of the text was carefully planned, taking into account several aspects which were expected to affect the students' translation performance. In order to show their real level of Chinese-English translation, they were not allowed to use any electronic tools as their assistants. In this study, the following table 1 shows the number and distribution of scores of the 30 samples (from 60) in the correcting website named "Corrects A Cool Web".

TABLE I FREQUENCY DISTRIBUTION OF 30 SAMPLES' SCORES

\begin{tabular}{|c|c|c|c|c|c|}
\hline Scores & $68-69$ & $71-75$ & $76-79$ & $80-85$ & $87-88$ \\
\hline Data & 2 & 7 & 7 & 9 & 5 \\
\hline Percentage & $6.7 \%$ & $23.3 \%$ & $23.3 \%$ & $30 \%$ & $16.7 \%$ \\
\hline
\end{tabular}

\section{RESULTS AND DISCUSSION}

The quantitative research in this study is to observe the percentage of translation problems in students' performance so as to find the distribution of translation problems and figure out the most serious problem in their translation. In order to analyze how students' translation competence can be developed based on discourse construction in a more scientific manner, the author takes advantage of the correcting website "Corrects A Cool Web" which can automatically identify the vocabulary, collocation, grammar and other common mistakes and give suggestions for revision. With the great help of the correcting website, we have found out four representative and typical translation problems in the 30 translations, namely lack of coherence and cohesion, default of sentence structure, misuse of words and collocation mistakes.

\section{A. The most frequent errors in the student translations}

The source text is a short but complete paragraph extracted from a news article about the positive impact of the Internet on China's economy. The translation of this text should be standard and precise.

\section{1) Lack of coherence and cohesion.}

About $60 \%$ students tries to use logical phrases like "on the one hand, on the other hand, last but not least etc." and pronounce "it" as cohesive devices but has failed to use them in a right way. The reason for it may be that they don't have the consciousness of discourse analysis so that they cannot figure out the logical way of the source text from the point of the whole text. Then nearly $33.3 \%$ students pay attention to cohesive devices in his translation due to their not solid basis of English and lack of awareness of cohesion. Unfortunately, only $6.7 \%$ students have done a good job in this section. The following table 2 shows the numbers and distribution of students' situation in lack of cohesion.

TABLE II FREQUENCY DISTRIBUTION OF STUDENTS' PERFORMANCE IN LACK OF COHESION

\begin{tabular}{|c|c|c|c|}
\hline Situation & $\begin{array}{c}\text { Hardly use } \\
\text { cohesive } \\
\text { devices }\end{array}$ & $\begin{array}{c}\text { use them } \\
\text { inappropriately }\end{array}$ & $\begin{array}{c}\text { Use them } \\
\text { appropriately }\end{array}$ \\
\hline $\begin{array}{c}\text { number of } \\
\text { students }\end{array}$ & 10 & 18 & 2 \\
\hline Percentage & $33.3 \%$ & $60 \%$ & $6.7 \%$ \\
\hline
\end{tabular}


As to COHERENCE, there are two methods to make textual coherence. One is the use of lexical means and the other is the rational sort of information. As is observed, some students have the intention to realize textual coherence but owing to lack of sufficient practice of profound analysis of the inner connections of the source text. Some other students may even have not realized that they are supposed to focus on the textual coherence. The following table shows the numbers and distribution of students' situation in lack of coherence.

TABLE III FREQUENCY DISTRIBUTION OF STUDENTS' SITUATION IN LACK OF COHERENCE

\begin{tabular}{|c|c|c|}
\hline Situation & $\begin{array}{c}\text { hardly use } \\
\text { textual coherence }\end{array}$ & $\begin{array}{c}\text { use the lexical means } \\
\text { to } \\
\text { achieve textual } \\
\text { coherence }\end{array}$ \\
\hline $\begin{array}{c}\text { number of } \\
\text { students }\end{array}$ & 11 & 19 \\
\hline Percentage & $36.7 \%$ & $63.3 \%$ \\
\hline
\end{tabular}

2) Default of Sentence Structure.

Some of translations like (1) "It makes the connection between the production takes more direct reduce and the intermediate links, thus greatly reduced the cost, then improve the economic efficiency.", (2) "It makes the relationship between production and consumption more direct, reduce the intermediate links, thus greatly reduced the cost, improve the economic efficiency." and (3) "It makes the connection between production and consumption more direction, so that it can reduce a lot of intermediate links, lowering the cost and advancing the efficiency of the economy's operation." are almost ubiquitous.

From these examples it's known that those students haven't figured out the correct logic of the source sentence and haven't transferred their thinking pattern successfully from Chinese to English. The basic rules in English sentence structure can be that in one sentence there should be only one predicate while the above two sentences (1) \& (2) use four predicates as showed in bold type, and that causative verb like "make" should be followed by an adjective or the base form of a verb instead of a noun as the above sentence (3) who is supposed to use not the noun "direction" but the adjective "direct" after the verb "makes". There are many other versions of this sentence's translation, but they share the characteristic that no one is correct both logically and grammatically.
3) Misuse of Words

The following table 4 shows the misuse of some key words and the percentage.

TABLE IV FREQUENCY DISTRIBUTION OF STUDENTS' SITUATION IN MISUSE OF WORDS

\begin{tabular}{|l|l|l|}
\hline word & Misuse of words & percentage \\
\hline economic & economy & $6.7 \%$ \\
\hline $\begin{array}{l}\text { Producing and } \\
\text { consuming }\end{array}$ & $\begin{array}{l}\text { production and } \\
\text { consumption }\end{array}$ & $6.7 \%$ \\
\hline connect & connection & $6.7 \%$ \\
\hline constantly & continually & $3.3 \%$ \\
\hline
\end{tabular}

4) Collocation mistakes

In the source text, the main obstacle for students to translate is six phrases, that is "Reform and Opening up)", "main driving force", "technological development", "intermediate links", "economic efficiency)" and "there is no doubt". The following table 5 presents the percentage of errors from students' translations.

TABLE V PERCENTAGE OF ERRORS

\begin{tabular}{|c|l|}
\hline expressions & \multicolumn{1}{|c|}{$\begin{array}{c}\text { Incorrect collocation (percentage of } \\
\text { errors) }\end{array}$} \\
\hline Reform and & $\begin{array}{l}\text { Reform and openness, reform and } \\
\text { opening, reform, revolution, reform } \\
\text { and open, reform and opening up } \\
\text { policy (67\%) }\end{array}$ \\
\hline main driving force & $\begin{array}{l}\text { Main strength, main power, main } \\
\text { driver, main force, main driving } \\
\text { power, major power, major strength } \\
\text { (30\%) }\end{array}$ \\
\hline technological & $\begin{array}{l}\text { Science development, science and } \\
\text { technology, development of science } \\
\text { (80\%) }\end{array}$ \\
\hline intermediapment links & $\begin{array}{l}\text { The middle part, middle link, } \\
\text { intermediate process (10\%) }\end{array}$ \\
\hline economic efficiency & $\begin{array}{l}\text { Efficiency of economic operation, the } \\
\text { efficiency of economic running, } \\
\text { economic operational efficiency, } \\
\text { economic operational efficiency, } \\
\text { efficiency of economic operation, } \\
\text { efficiency economic execution (75\%) }\end{array}$ \\
$\begin{array}{l}\text { There is no denying the fact that, there } \\
\text { is no deny that, never can we deny } \\
\text { that, needless to say (25\%) }\end{array}$ \\
\hline there is no doubt
\end{tabular}

\section{B. Translation errors in relation to translation competence}

In the translation model of the PACTE research group[7], translation competence consists of several sub-competences, In order to solve translation problems, students have to draw on their extra-linguistic sub-competence and bicultural knowledge. In the competence model of the PACTE research 
group, strategic sub-competence has a central role as it is a sort of meta-competence which includes all the strategies used to compensate for insufficient translation competence and monitor the whole translation. Thus it's teachers' role to develop the sub-competences through various tasks and activities. The following table 6 shows the distribution of students' situation in four problems, namely, lack of coherence and cohesion, default of sentence structure, misuse of words and collocation mistakes.

TABLE VI FREQUENCY DISTRIBUTION OF STUDENTS' SITUATION IN FOUR PROBLEMS

\begin{tabular}{|l|l|}
\hline \multicolumn{1}{|c|}{ Situation } & Percentage \\
\hline Lack of coherence and cohesion (A) & $65 \%$ \\
\hline Default of sentence structure (B) & $100 \%$ \\
\hline Misuse of words (C) & $6.7 \%$ \\
\hline Collocation mistakes (D) & $33.3 \%$ \\
\hline
\end{tabular}

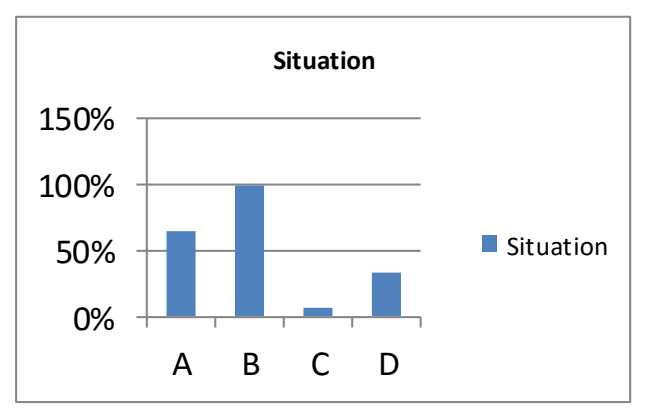

Fig. 1. Example of a figure caption.

From the above chart (fig.1), it's known that discourse construction is the basis and essence of translation competence. The solution to lack of coherence and cohesion counts on the improvement of the English discourse capability. Diction, collocation and syntax are essential elements in translation performance.

\section{CONCLUSION}

Klaudy [4] argues that translation is a highly complex decision-making process, in which translators have to make choices and perform several actions, which she calls "transfer operations". Such transfer involves sub-competences. The results of analysis of the students' translations show that most of errors occur at the language level but the origin of these errors are often beyond the linguistic level. A good way to help students to develop the translation competence is to establish discourse awareness and conducting various in-class activities and after-class assignments including translation elements. It is necessary to apply the discourse analysis theory to the students' translation practice, since it can not only help them find the right direction of thinking, but also guide them to make a comparison between the similarities and differences of the English and Chinese texts and make a correct judgment in compliance with the logical thinking so that it is possible for them to acquire translation competence.

\section{REFERENCES}

[1] Beaugrande, R. de\& W. Dressler. Introduction to Text Linguistics [M]. London: Longman, 1981.

[2] Halliday, M.A.K \& R. Hasan, Cohesion in English [M]. London: Longman Group U. K. limited, 1976.

[3] Hatim, B. \& I, Mason, Discourse and the Translator [M]. Shanghai: Shanghai Foreign Language Education Press, 2001.

[4] Klaudy, K., Language in translation: Lectures on the theory, teaching, and practice of translation[M]. Budapest:Scholastica, 2003.

[5] Melis, N.M., \& Albir, A.H , Assessment in translation studies: Research needs. Meta, 46(2) 2001.

[6] Nord, Text Analysis in Translation:Theory,Methodology, and didactic application of a model for translation-oriented text analysis[M]. Amsterdam: Rodopi, 1991.

[7] PATCE, Results of the validation of the PATCE translation competence model: Translation project and dynamic translation index.in S.O'Brien(Ed.), Cognitive explorations of translation(pp30-53). London: continuum, 2011.

[8] Svetlana K. Gural, Stepan A. Boyko, Procedia-Social and Behavioral Sciences,Analysis of the Literary Text's Conceptosphere in the Process of Teaching Literary Translation -J/OL www.sciencedirect.com ., 2014.

[9] Wu Wei, On Discourse and Discourse Translation from the Perspective of Discourse Analysis[J], Journal of Hubei RTV University, 2008 (in Chinese)

[10] Zhang Meifang's, Information Transformation in English-Chinese Translation[J] Foreign Language Teaching and Research, 2000 (in Chinese) 